\title{
DIVERSIFIKASI DAN PENANGANAN PASCA PRODUKSI OLAHAN IKAN DI DESA PADANG JAYA BENGKULU UTARA UNTUK MENINGKATKAN NILAI EKONOMI DAN PENDAPATAN MASYARAKAT
}

\section{DIVERSIFICATION AND POST PRODUCTION OF PROCESSED FISH IN PADANG JAYA NORTH BENGKULU ON INCREASING THE ECONOMIC VALUE AND COMMUNITY INCOME}

\author{
Oleh: \\ Devi Ratnawati, Agus Martono Hadi Putranto, dan Devi Rizanty \\ Jurusan Kimia Universitas Bengkulu \\ devi_r64@yahoo.com
}

\begin{abstract}
The first aim of this activity is giving knowledge to farmer society of fish specially Unit Pengolahan Ikan ( UPI) Melati I in Padang Jaya Village North Bengkulu about diversification of multifarious product which have higher level economic value. The second aim is giving processing practice of some alternative multifarious fish based product to be industrial product which have high economic value. It is also using natural pickling method, so that it is a good product for healthy life. The practice also gives training in making safe packaging and product marketing. While, special target is to improve knowledge of breeder of fish specially Unit Pengolahan Ikan (UPI) Melati I as participant of training about diversified multifarious of fish product that having higher level economic value and practice some alternative product of fish become multifariously of industrial product which have value sell economical, like fish rengginang, cryspy fish baby and fish of salai. Including handling of after production ie. marketing and packaging. This activity walk better, its product even also have earned to be marketed out of Desa Padang Jaya, ie. Bengkulu town and Jakarta, and become typical pledge present of desa Padang Jaya. Request of this produst even also mount, this matter because of its product have registering PIRT and get lawful lable so that society feel safe to consuming it.
\end{abstract}

Keywords: Diversification, fish processing, UPI Melati I, Padang Jaya

\section{PENDAHULUAN}

Pangan merupakan salah satu kebutuhan pokok yang sangat penting dalam kehidupan manusia. Pengolahan dan pengawetan bahan makanan memiliki interelasi terhadap pemenuhan gizi masyarakat, maka tidak mengherankan jika semua negara baik negara maju maupun berkembang selalu berusaha untuk menyediakan suplai pangan yang cukup, aman dan bergizi. Salah satunya dengan melakukan berbagai cara diversifikasi pengolahan produk dan pengawetan pangan yang dapat memberikan variasi hasil olahan dan perlindungan terhadap bahan pangan yang akan dikonsumsi. 
Bahan pangan secara umum bersifat mudah rusak (perishable), karena kadar air yang terkandung di dalamnya sebagai faktor utama penyebab kerusakan pangan itu sendiri. Semakin tinggi kadar air suatu pangan, akan semakin besar kemungkinan kerusakannya baik sebagai akibat aktivitas biologis internal (metabolisme) maupun masuknya mikroba perusak. Kriteria yang dapat digunakan untuk menentukan apakah makanan tersebut masih pantas di konsumsi, secara tepat sulit di laksanakan karena melibatkan factor-faktor nonteknik, sosial ekonomi, dan budaya suatu bangsa. Idealnya, makanan tersebut harus: bebas polusi pada setiap tahap produksi dan penanganan makanan, bebas dari perubahanperubahan kimia dan fisik, bebas mikroba dan parasit yang dapat menyebabkan penyakit atau pembusukan (Winarno,1993:25).

Salah satu bahan makanan yang dikonsumsi sehari-hari adalah ikan air tawar seperti ikan nila dan mas. Kenaikan produksi budidaya ikan dalam kolam air tawar pun cukup pesat yaitu berkisar 11 persen setiap tahun (Sugito, 2013). Hal ini menujukkan ada gairah besar di masyarakat untuk mengembangkan usaha budidaya ikan air tawar. Dengan luasnya kolam ikan yang ada, maka produksi ikan pun mengalami peningkatan (Alam Tani, 2013).

Salah satu daerah sentra perikanan air tawar di Bengkulu Utara adalah desa padang jaya, Kecamatan Padang Jaya, Kabupaten bengkulu utara. Kabupaten Bengkulu Utara juga terkenal sebagai penghasil perikanan air tawar terbesar di provinsi Bengkulu. $40 \%$ total produksi ikan air tawar provinsi Bengkulu adalah dari Bengkulu Utara dan telah ditetapkan sebagai Minapolitan perikanan air tawar (Azbaz, 2013). Berbagai prestasi dan penghargaan telah diperoleh baik skala daerah maupun nasional dalam hal keberhasilan pengembangan sentra produksi ikan air tawar dalam rangka pengentasan kemiskinan di desa Padang jaya bengkulu utara. Usaha budidaya perikanan air tawar di Kabupaten Bengkulu Utara didukung oleh Balai Benih Ikan pemerintah daerah, Balai Pengembangan Budidaya Air Tawar (BPBAT) di Marga Sakti, dan Kolam Air Deras di desa Pagar Ruyung. Jumlah Balai Benih Ikan dan Balai Pengembangan Budidaya Air Tawar (BPBAT), dan Kolam Air Deras (KAD) di Kabupaten Bengkulu Utara. PUMP (Pengembangan Usaha Mina Pedesaan) di Kabupaten Bengkulu Utara telah dilaksanakan sejak tahun 2011. Hingga tahun 2013, PUMP-PB telah menyalurkan dana bantuan Rp. 1.505.000.000,- kepada 21 kelompok pembudidaya ikan di kawasan minapolitan ini (BPUMKM, 2011).

Dengan luas kolam ikan yang mencapai $500 \mathrm{Ha}$, produksi 3 ton/kolam/3 bulan, maka dihasilkan sekitar 1.500 ton ikan air tawar segar siap konsumsi, suatu jumlah yang sangat fantastis. Saat panen raya, ikan air tawar segar dihargai Rp 16.000/Kg nya, diluar harga normal saat ini, yaitu Rp. 23.000/Kg dari petani ke pengepul. Kegiatan budidaya perikanan di Kecamatan Padang jaya masih terbatas pada peningkatan produksi, sehingga belum terdapat keterkaitan antara pembudidaya, pengolah dan pemasaran hasil perikanan secara berkelanjutan. Akibatnya pada saat over produksi, produk perikanan belum terserap sepenuhnya dipasaran, harganya pun turun drastis dimana sebagian besar masih dijual dalam bentuk ikan segar. Melihat prospek yang besar terhadap hasil petani ikan di wilayah 
ini, munculah Unit Pengolahan Ikan (UPI) Melati I yang bergerak di bidang pengolahan ikan segar menjadi ikan asap (ikan salai) dan ikan krispi (baby fish). Berbagai prestasi dan penghargaan telah diterima oleh kelompok ini karena telah menjadi satu-satunya kelompok unit pengolahan ikan di Bengkulu Utara dan berhasil memberdayakan masyarakat dalam rangka pemberdayaan sumberdaya lokal untuk mengentaskan kemiskinan dan pendapatan masyarakatnya. Namun jenis produk olahan perikanan yang dihasilkan masih sangat sedikit apabila dibandingkan dengan jumlah produksi ikan segar.

Berdasarkan uraian di atas diketahui bahwa diperlukan suatu upaya diversifikasi atau pengembangan produk olahan ikan sebagai salah satu upaya untuk mengatasi rendahnya harga ikan air tawar yang merosot, antara lain dengan mengolahnya menjadi rengginang ikan, baby fish crispy dan ikan salai. Proses pengawetannya menggunakan metode alami, pengasapan dan pengeringan supaya tidak membahayakan kesehatan. Ikan yang telah diolah menjadi produk yang bernilai komersil tersebut diharapkan akan mempunyai nilai jual jauh lebih tinggi jika dibandingkan dengan sebelum diolah, karena selain produknya tahan lama, variatif, unik dan kreatif, produk tersebut sangat aman bagi kesehatan karena menggunakan cara pengawetan yang alami. Melalui terobosan tersebut, diharapkan peternak ikan di Desa Padang Jaya sebagai sentra penghasil ikan air tawar di Propinsi Bengkulu dapat lebih mempertahankan dan meningkatkan taraf ekonomi pendapatannya, serta yang terpenting adalah para peternak pengusaha kecil yang bergerak di usaha tani budidaya tanaman ikan dapat terus exist ditengah harga ikan air tawar yang merosot.

\section{METODE PENGABDIAN}

Metode penerapan iptek ini diberikan dalam bentuk penyuluhan dan demonstrasi atau praktek.

a. Kegiatan penyuluhan

Kegiatan ini diberikan kepada kelompok peternakikan dan kelompok Unit Pengolahan Ikan (UPI) MELATI I (jumlah 40 orang) di Desa Padang Jaya Bengkulu Utara. Peserta diberi bekal tentang aneka pengolahan produk dari ikan dan pengawetannya secara alamiah beserta stategi pemasaran yang lebih luas.

b. Demonstrasi atau praktek

Teknik ini digunakan untuk memperlihatkan secara langsung tentang cara pengolahan ikan menjadi aneka industri rumah tangga yang mempunyai nilai ekonomi. Kegiatan ini diikuti oleh peternak, kelompok UPI MELATI I dan atau peserta pelatihan di kawasan kegiatan, beberapa kelompok ibu PKK dan penduduk di kawasan sekitar. Kegiatan ini merupakan kegiatan untuk mempraktekkan pengolahan ikan menjadi aneka produk olahan yang lebih bernilai jual.

Pelaksanaan demonstrasi atau praktek di lapangan dilakukan dengan cara membagi peternak menjadi 3 kelompok (masing-masing kelompok terdiri dari 13 orang), kemudian 
masing-masing kelompok diberi pengarahan tentang pengolahan ikan menjadi : rengginang ikan, ikan salai dan baby fish crispy, dengan Pembagian kelompok adalah sebagai berikut:

Kelompok 1 : Pengolahan ikan menjadi rengginang ikan

Kelompok 2 : Pengolahan ikan menjadi ikan salai

Kelompok 3 : Pengolahan ikan menjadi baby fish crispy

\section{Tahap-Tahap Pelaksanaan}

Tahap-tahap pelaksanaan pengabdian ini adalah sebagai berikut :

1. Tahap persiapan, dilakukan persiapan-persiapan di lapangan yang meliputi penyediaan alat-alat lapangan, survey tempat kegiatan, perizinan, memperkirakan keadaan tempat kegiatan serta pendataan jumlah dan peserta kegiatan

2. Tahap penyuluhan, dilakukan penyuluhan tentang pentingnya pengolahan ikan segar menjadi aneka produk bernilai ekonomis tinggi, prosedur pemilihan jenis ikan segar yang dapat diolah, dan tahapan proses pengolahan aneka produk, serta pentingnya dilakukan pengawetan produk hasil olahan secara alamiah sekaligus strategi pemasarannya.

3. Tahap peragaan, demonstrasi dan praktek, dilakukan peragaan, demonstrasi dan praktek tentang proses pengolahan ikan segar menjadi aneka produk bernilai ekonomis tinggi dan layak jual. Selain itu, dilakukan praktek cara pengawetan secara alamiah terhadap produk hasil olahan.

4. Tahap evaluasi, dilakukan evaluasi terhadap semua kegiatan, hasil penyuluhan dan kegiatan akhir

5. Tahap pelaporan, dilakukan pelaporan terhadap semua kegiatan yang telah dilakukan dalam bentuk laporan akhir dan pertanggungjawaban.

\section{Prosedur pembuatan rengginang ikan}

1. Kukus beras ketan sampai mekar selama 30 menit, lalu angkat.

2. Masak (Aron) ketan dengan air kelapa yang telah dicampur dengan bumbu halus, daging ikan dan pewarna makanan. Kukus kembali hingga matang selama 45 menit (jika ingin berwarna pelangi/ rainbow, bagi adonan sesuai pilihan warna).

3. Ambil 1 sendok makan ketan kemudian pipihkan di tampah. Jemur ketan yang telah dipipihkan tadi di bawah sinar matahari sampai kering merata (sekitar 2 hari/ tergantung cuaca). Jika satu sisi kering, balik rengginang agar kering merata. Angkat.

4. Setelah kering, goreng dalam minyak goreng yang sudah dipanaskan di atas api sedang sampai matang. Tiriskan kemudian kemas dalam plastik yang kedap udara.

Prosedur pembuatan baby fish crispy (Sebelah, 2012)

1. Siapkan $2 \mathrm{~kg}$ ikan segar, pilih yang kecil, bersihkan.

2. Rendam ikan dalam air cuka, kemudian cuci. 
3. Beri garam secukupnya kemudian campur dengan tepung (tepung beras : tepung sajiku $=1: 1)$

4. Goreng dalam minyak panas sampai berwarna kecoklatan, tiriskan dan keringkan minyak dengan cara diputar dalam mesin pemutar (bisa menggunakan pengering mesin cuci)

5. Kemas dalam plastik kedap udara

6. Siap dipasarkan.

\section{Prosedur pembuatan ikan salai}

1. Bersihkan ikan dari sirip, tulang dan bagian lain yang tidak diinginkan lalu cuci hingga bersih.

2. Belah ikan lele menjadi 2 bagian.

3. Daging lele yang sudah dibelah ditaruh di nampan besi, lalu masukkan ke dalam mesin pengasap.

4. Nyalakan api dari kayu, daging ikan lele diasapi sampai kering.

5. Kemas dalam kemasan yg sudah disediakan.

6. Ikan Salai siap dipasarkan.

\section{HASIL DAN PEMBAHASAN}

Kegiatan pengabdian masyarakat telah di lakukan di Desa Padang Jaya Bengkulu Utara yang merupakan desa sentra ikan air tawar (Minapolitan) di Bengkulu. Ada pun beberapa kegiatan yang telah dilakukan adalah :

1. Tahap persiapan, dilakukan persiapan-persiapan di lapangan yang meliputi penyediaan alat-alat lapangan, survey tempat kegiatan, perizinan, memperkirakan keadaan tempat kegiatan serta pendataan jumlah dan peserta kegiatan. Kegiatan ini telah dilaksanakn pada bulan Juni 2014. Berdasarkan hasil survey, kegiatan ini akan dilakukan di rumah ibu sunarti yang merupakan sentra produksi olahan ikan di desa padang jaya. Kegiatan ini telah mendapat izin dari ketua kelompok UPI, Rt dan rumah pusat produksi.

2. Tahap penyuluhan, dilakukan penyuluhan tentang pentingnya pengolahan ikan segar menjadi aneka produk bernilai ekonomis tinggi, prosedur pemilihan jenis ikan segar yang dapat diolah, dan tahapan proses pengolahan aneka produk, serta pentingnya dilakukan pengawetan produk hasil olahan secara alamiah sekaligus strategi pemasarannya. Kegiatan penyuluhan ini mendapat reaksi yang positif yang ditunjukkan oleh antusiasme anggota kelompok untuk mengetahui prosedur pengolahan ikan segar menjadi produk lain yang lebih komersial.

3. Tahap peragaan, demonstrasi dan praktek, dilakukan peragaan, demonstrasi dan praktek tentang proses pengolahan ikan segar menjadi aneka produk bernilai ekonomis tinggi dan layak jual. Selain itu, dilakukan praktek cara pengawetan secara alamiah 
terhadap produk hasil olahan. Kegiatan ini membutuhkan beberapa hari sampai diperoleh produk final, karena ada yang memerlukan penjemuran di sinar matahari dan proses pengasapan yang memakan waktu lama. Namun hal itu tidak menyurutkan semangat anggota kelompok untuk mengikuti proses kegiatan pengabdian masyarakat.

4. Tahap evaluasi, dilakukan evaluasi terhadap semua kegiatan, hasil penyuluhan dan kegiatan akhir.

Evaluasi keberhasilan kegiatan ini dilakukan melalui :

a. Relevansi (Relevance)

Ada kesesuaian antara misi program dan sumberdaya yang tersedia. Kegiatan ini bertujuan untuk memberdayakan sumber daya yang ada, dimana ikan segar diproduksi secara melimpah di daerah ini. Ikan segar ini diolah menjadi produk makanan yang bernilai komersil lebih tinggi.

\section{b. Efisiensi dan produktivitas (efficiency and productivity)}

Kegiatan yang dilakukan berdampak pada peningkatan pendapatan peternak dan atau peserta pelatihan. Setelah dilakukan diversifikasi produk olahan ikan segar, permintaan hasil olahan semakin meningkat. Hal ini menjadikan produk ini sebagai oleh-oleh khas Desa Padang Jaya Bengkulu Utara. Peminat terbesar nya justru dari wilayah Provinsi Bengkulu dan kabupaten argamakmur, namun hal ini tidak menjadi kendala karena transportasi sudah semakin maju, proses pengiriman juga tidak menjadi hambatan.

\section{c. Keberlanjutan (sustainability)}

Kegiatan yang dilakukan dapat dilaksanakan secara berkelanjutan. Produksi olahan ikan terus berlanjut sampai saat ini, dikarenakan pesanan akan produk olahan semakin banyak. Pasar tradisional pun sudah mulai memasarkannya, khususnya ikan salai atau yang dikenal dengan ikan lele asap. Produksi rengginang ikan dan baby fish crispy juga semakin meningkat seiring dengan makin banyaknya pesanan dari luar Desa Padang Jaya.

\section{d. Luas cakupan (scope of implementation)}

Sejauh mana kegiatan ini dapat diadopsi oleh peserta pelatihan? Berdasarkan hasil kegiatan bahwa teknologi atau IPTEK yang diterapkan dalam kegiatan pengabdian ini dapat diadopsi oleh kelompok UPI melati I yang merupakan kelompok yang memproduksi olahan ikan segar. Hal ini disebabkan karena teknologi bersifat sederhana dan mudah diaplikasikan pada skala produksi mereka.

\section{KESIMPULAN DAN SARAN}

\section{Kesimpulan}

1. Kegiatan pengabdian ini telah mengolah ikan segar menjadi ikan salai, rengginang ikan dan baby fish crispy.

2. Produksi hasil olahan tersebut terus berlanjut sampai dengan sekarang. 
3. Produksi hasil olahan ikan semakin banyak karena pesanan dari luar kota juga semakin meningkat.

\section{Saran}

Promosi hendaknya dilakukan lebih optimal dengan menggunakan media sosial atau internet sehingga produk olahan ikan Padang Jaya dapat lebih dikenal oleh khalayak luas.

\section{DAFTAR PUSTAKA}

Alam Tani, 2013, Potensi Usaha Budidaya Ikan Air Tawar. http://www.alamtani.com/ikan-air-tawar.html

Azbaz, 2013, Bidang Perikanan Budidaya Dinas Kelautan Dan Perikanan, Bengkulu.

BPUMKM, 2011, Pola Pembiayaan Usaha Kecil Syariah (PPUK-Syariah), Direktorat Kredit, BPR dan UMKM (BUMKM-DKBU), Bank Indonesia.

Sebelah, 2012, Resep Cara Membuat Ikan Lele Spesial.

Sugito, 2013, Budidaya Lele Sejahterakan Warga Srikaton, Bengkulu Tengah.

Winarno, F.G.I., 1993, Pangan, Gizi, Teknologi dan Konsumsi, Jakarta, Gramedia Pustaka.

\section{FOTO KEGIATAN}

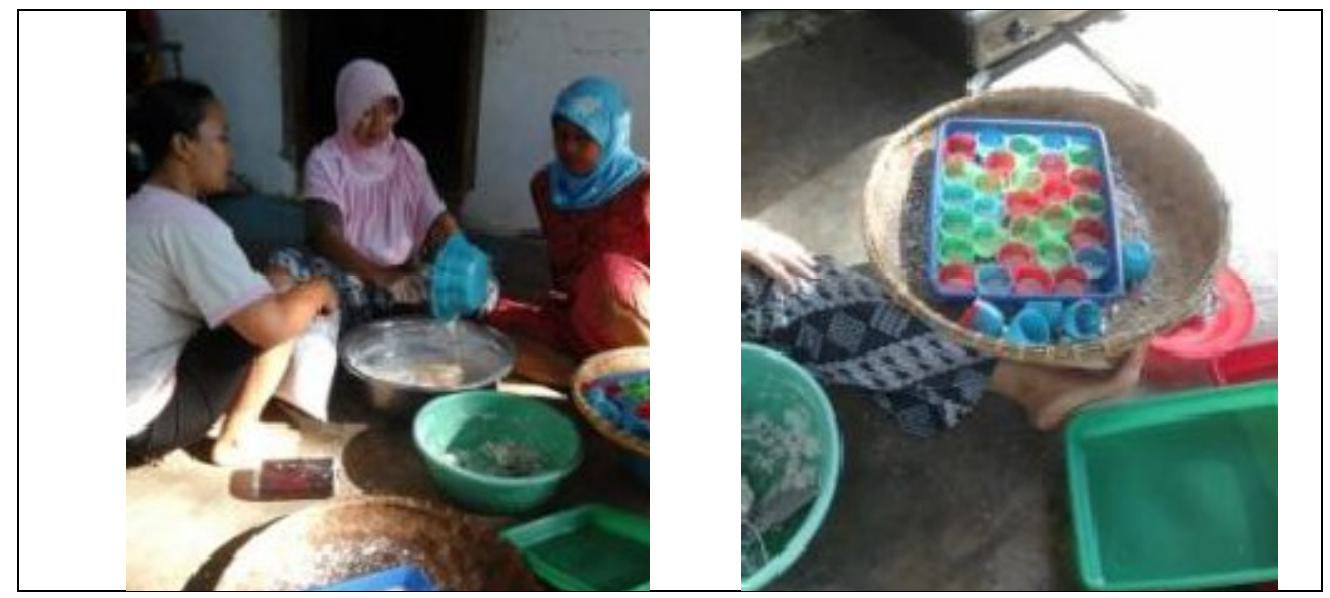




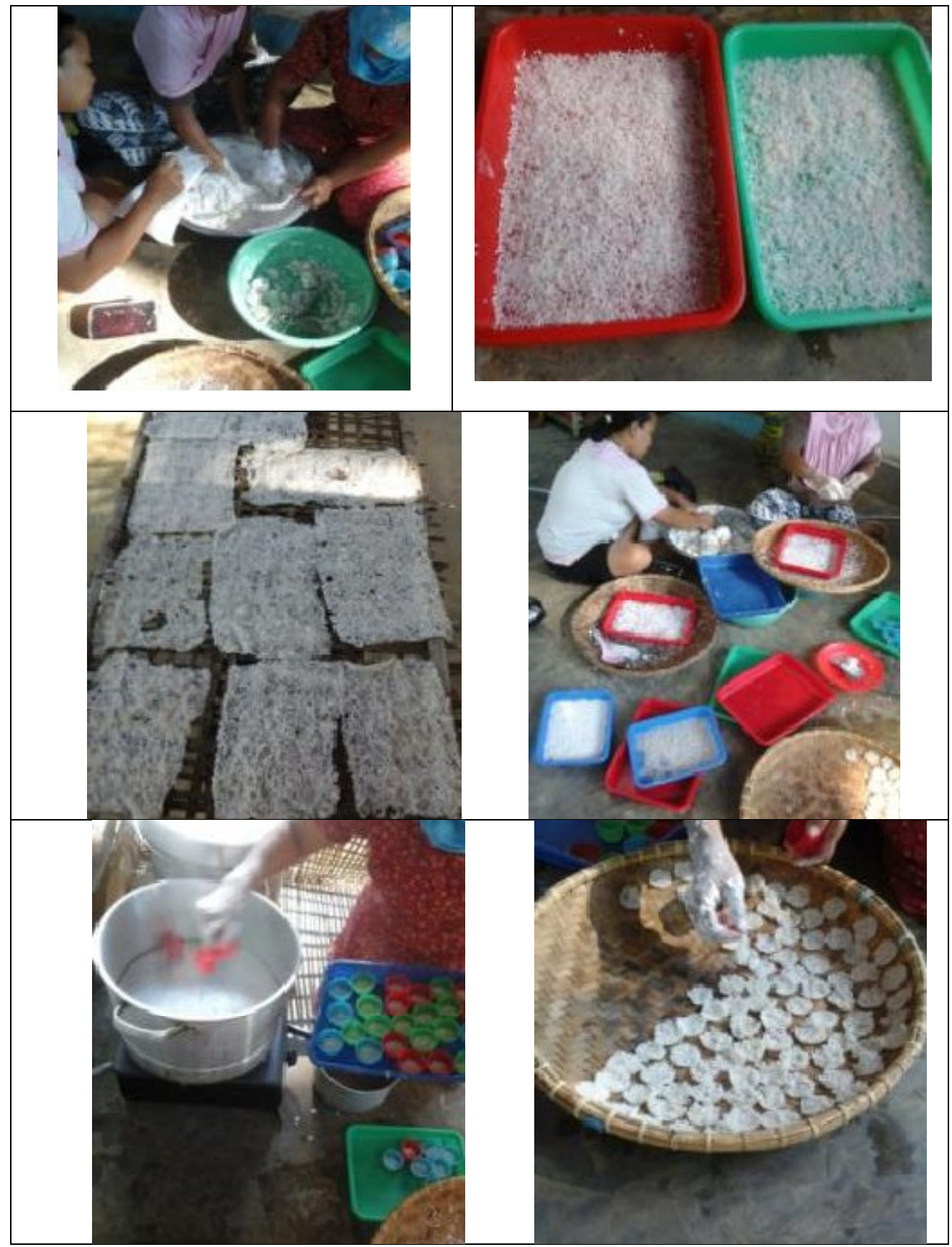




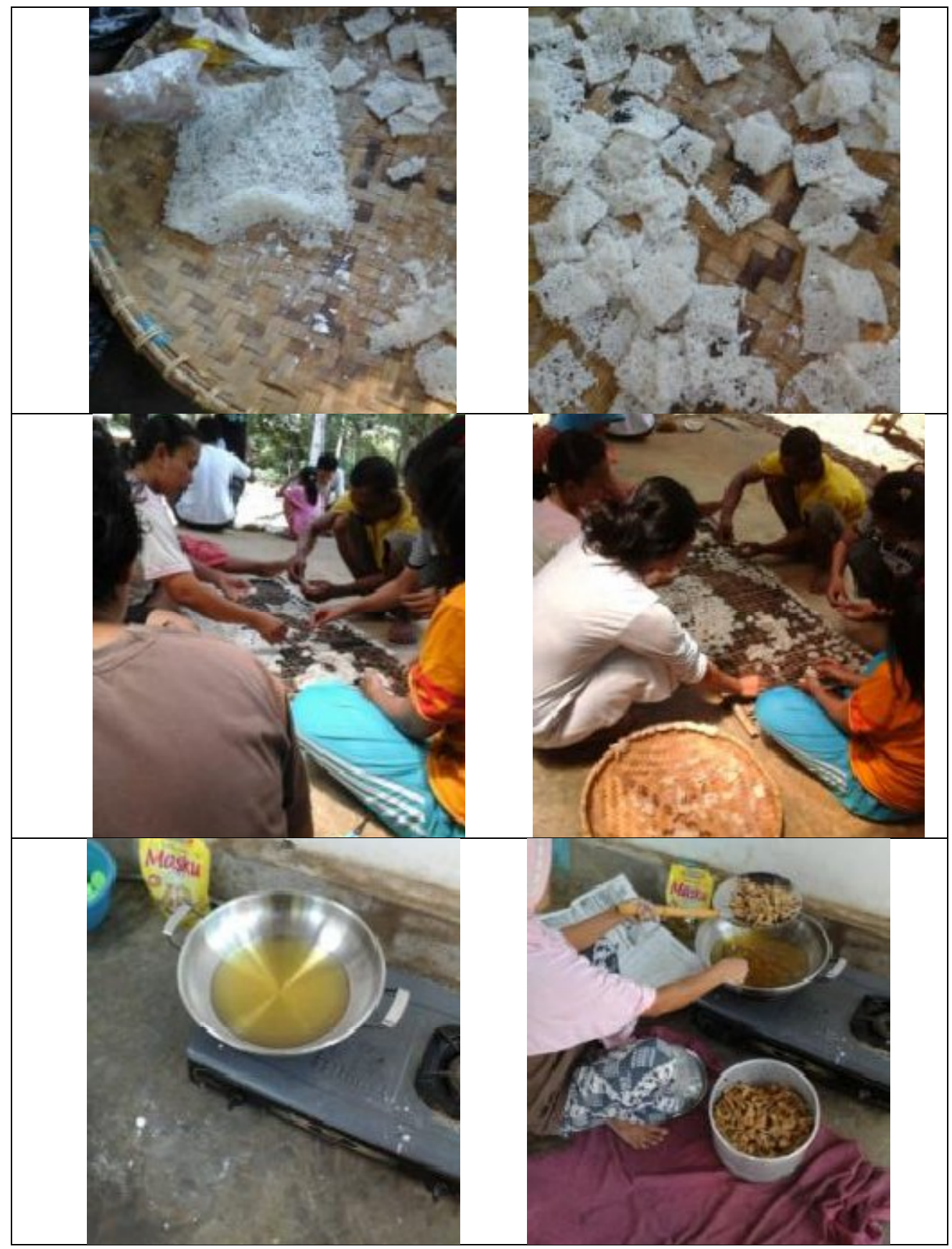




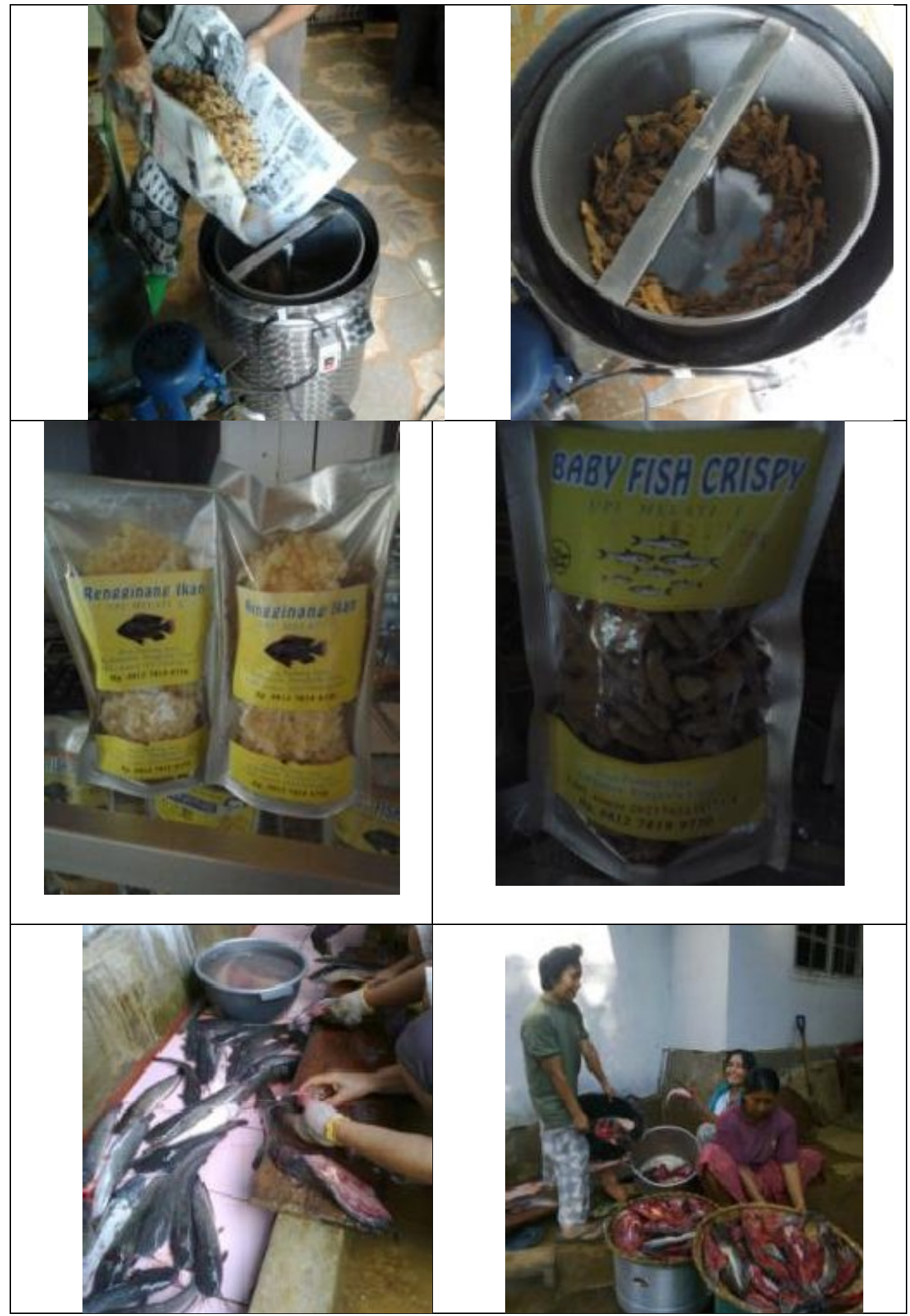




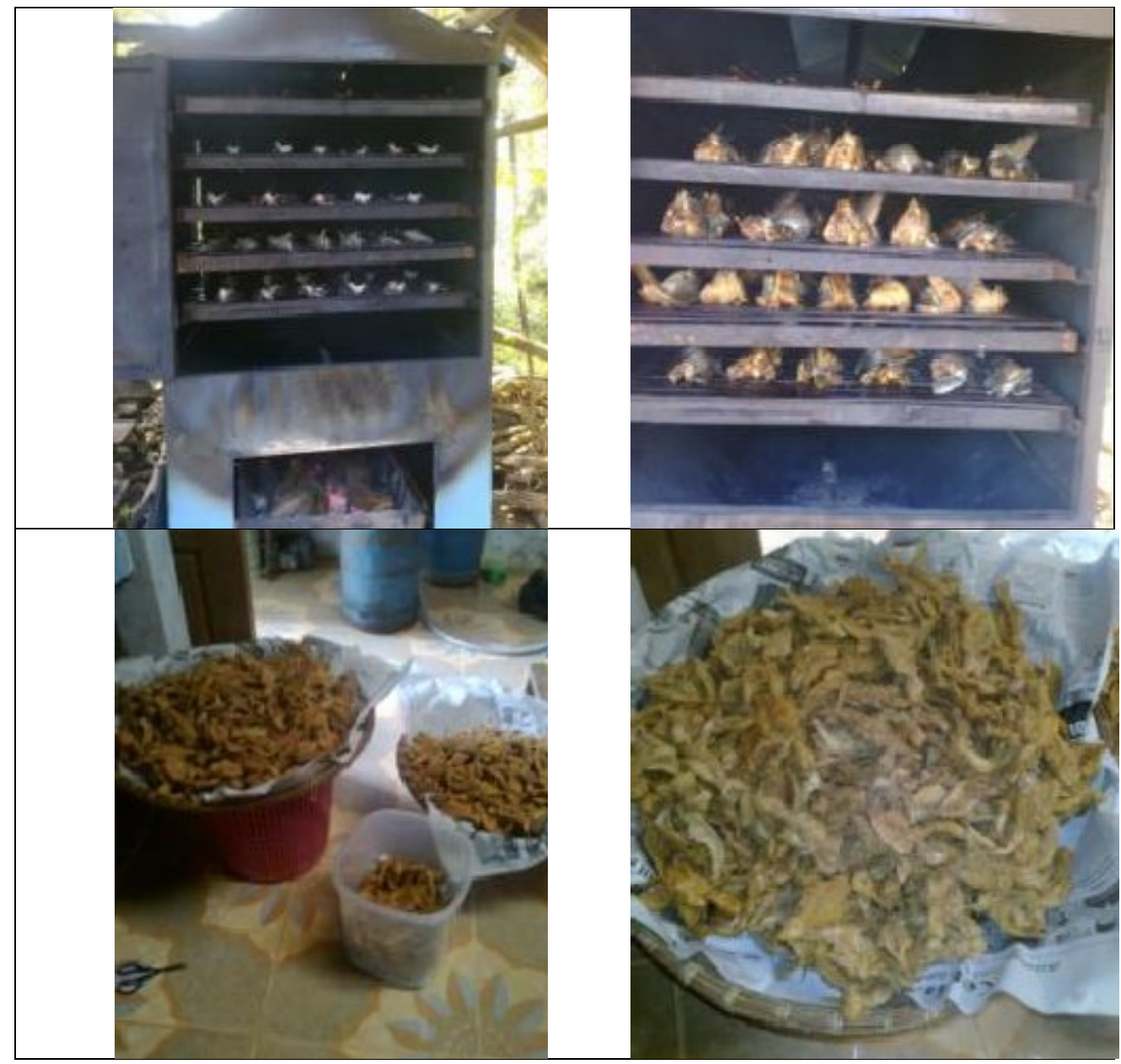

